ISSN 0258-7122

Bangladesh J. Agril. Res. 40(4): 619-628, December 2015

\title{
EFFECT OF NITROGEN ON DIFFERENT GENOTYPES OF MUNGBEAN AS AFFECTED BY NITROGEN LEVEL IN LOW FERTILE SOIL
}

\author{
M. A. RAZZAQUE ${ }^{1}$, M. M. HAQUE ${ }^{2}$, M. A. KARIM ${ }^{3}$ \\ A. R.M. SOLAIMAN ${ }^{4}$ AND M. M. RAHMAN ${ }^{5}$
}

\begin{abstract}
A pot experiment was conducted at Bangabandhu Sheikh Mujibur Rahman Agricultural University, Gazipur during kharif- II season (August to November) of 2010 to find out the nitrogen acquisition and yield of mungbean genotypes affected by different levels of nitrogen fertilizer in low fertile soil. Ten mungbean genotypes viz. IPSA-12, GK-27, IPSA-3, IPSA-5, ACC12890053, GK-63, ACC12890055, BARI Mung-6, BUmug- 4 and Bina moog- 5 and six nitrogen fertilizer levels viz. $0,20,40,60,80$ and $100 \mathrm{~kg} \mathrm{~N}^{-1}$ were included as experimental treatments. Results indicated that increasing applied nitrogenous fertilizer in low fertile soil increased nitrogen acquisition of mungbean which increased number of pods plant ${ }^{-1}$ and seeds pod $^{-1}$ and finally increased yield of mungbean upto $60 \mathrm{~kg} \mathrm{~N}^{-1}$ irrespective of genotype and thereafter decreased. Genotype IPSA -12 produced the highest seed yield $\left(14.22 \mathrm{~g} \mathrm{plant}^{-1}\right)$ at $60 \mathrm{~kg} \mathrm{~N}$ $\mathrm{ha}^{-1}$. The lowest yield (7.33 $\mathrm{g}$ plant $^{-1}$ ) was recorded in ACC12890053 in control. From regression analysis, the optimum dose nitrogen for mungbean cultivation in the low fertile soil is $54 \mathrm{~kg} \mathrm{ha}^{-1}$.
\end{abstract}

Keyword: Yield, Nitrogen level, Nitrogen acquisition, Low fertile soil.

\section{Introduction}

Mungbean (Vigna radiata (L.) Wilczek) is an ancient and widely cultivated crop in many Asian countries including China, India, Pakistan, Philippines, Indonesia and Bangladesh (Akbari et al., 2008). Mungbean is a short duration crop and very effective for intensive cropping system. Mungbean can be easily fitted in mungbean - T. aus - T. aman (southern region), mungbean -T. aman wheat (north western region) and mungbean - aus - aman - potato (northern region) cropping systems without considering the fertility status of the soil (Haque, 2001). One of the reasons of ignoring soil fertility in mungbean cultivation is its ability to fixation of atmospheric nitrogen (Hardarson and Danso, 1993). However, amount of nitrogen fixed by microbial association varies over many soil and environmental factors which might not be sufficient for proper growth and yield formation of mungbean. Most of the researchers evaluated mungbean genotype in optimum soil

${ }^{1}$ Senior Scientific Officer, Training and Communication Wing, Bangladesh Agricultural Research Institute (BARI), Gazipur, ${ }^{2 \& 3}$ Professor, Department of Agronomy, Bangabandhu Sheikh Mujibur Rahman Agricultural University (BSMRAU), ${ }^{4}$ Professor, Department of soil science, BSMRAU, ${ }^{5}$ Professor, Department of Horticulture, BSMRAU, Gazipur, Bangladesh. 
condition but they ignored low nutrient environments for evaluation of mungbean (Anjum, et al., 2006; Akbari, et al., 2008 and Malik et al., 2002). There exists ample scope to evaluated mungbean genotypes that have inherent capability for producing higher yield under nutrient poor conditions. Therefore, the present study was undertaken with view to yield and nitrogen acquisition behavior of mungbean under low nitrogen condition in different nitrogen level.

\section{Materials and Method}

The pot experiment was conducted at Bangbandhu Sheikh Mujibur Rahman Agricultural University (BSMRAU), Gazipur during kharif II season (August to November) of 2010. The soil was used in this experiment belongs to Codda series, under Madhupur tract. The soil is called low fertile soil because nutrient content in soil below the critical limit in the fertilizer recommendation guide (FRG, 2005). The experimental pots were filled with $12 \mathrm{~kg}$ soil. Ten mungbean genotypes (IPSA-12, GK-27, IPSA-3, IPSA-5, ACC12890053, GK-63, ACC12890055, BARI Mung-6, BUmug- 4 and Bina moog- 5 and six nitrogen levels $\left(0,20,40,60,80\right.$ and $\left.100 \mathrm{~kg} \mathrm{~N} \mathrm{ha}^{-1}\right)$ were used as treatment variables.. Four (4) seeds per pot were sown on 31 August 2010. The treatments were factorial combination of the two factors and the experiment was conducted using a completely randomized design with four replication. One plant $\operatorname{pot}^{-1}$ was considered as one replication. Nitrogen fertilizers were top dressing at 15 days after sowing. All agronomic practices like two weeding (15 days and 30 days after emergence), three irrigation (12, 25 and 40 days after emergence) and one mulching was done at pod developing stage. Insect pest was controlled by spraying admire $0.5 \mathrm{ml}$ litre $^{-1}$ of water during the entire growth period of the crop. Genotypes differed in attainment of maturity and then the harvesting was done twice one on 31 October and another on 13 November, 2010.

Table 1. Chemical properties of the experimental soil before sowing.

\begin{tabular}{l|c|c}
\hline Soil properties & Present value & Critical level \\
\hline Organic matter $(\%)$ & 0.536 & - \\
Total N $(\%)$ & 0.05 & 0.10 \\
Available P (ppm) & 0.16 & 8.00 \\
Exchangeable K meg $100^{-1} \mathrm{~g}$ soil & 0.85 & 0.08 \\
Available S (ppm) & 7.00 & 8.00 \\
Available B $(\mathrm{ppm})$ & 0.15 & 0.16 \\
Available $\mathrm{Zn}(\mathrm{ppm})$ & 0.25 & 0.50 \\
Exchangeable Ca meg $100^{-1} \mathrm{~g}$ soil & 14.83 & 2.00 \\
Exchangeable Mg meg $100^{-1} \mathrm{~g}$ soil & 1.76 & 0.50 \\
CEC meg $100^{-1} \mathrm{~g}$ soil & 6.90 & $3-7.5$
\end{tabular}

Data on yield, yield components and nitrogen content of mungbean genotypes were recorded. Total nitrogen contents in plant were determined by modified 
Kjeldahl digestion colorimatric method (Cataldo et al., 1974). Nitrogen uptake by plant (shoot) of ten genotypes determined at maturity stage. The data on different parameters were subjected to statistical analysis Microsoft Excel and MSTAT C software programs were used wherever appropriate to perform statistical analysis.

\section{Results and Discussion}

\section{Plant height}

Genotype and nitrogen interacted significantly in plant height of mungbean (Table 2). Although plant height of mungbean increased with the increase of nitrogen levels but it attained peak differently in different genotypes treated by different nitrogen levels. Thus, the tallest plant $(63.66 \mathrm{~cm})$ of IPSA 12 was observed at $60 \mathrm{~kg} \mathrm{~N} \mathrm{ha}^{-1}$, GK $27(43.00 \mathrm{~cm})$ at $40 \mathrm{~kg} \mathrm{~N} \mathrm{ha}^{-1}$, IPSA $3(65.33 \mathrm{~cm})$ at $80 \mathrm{~kg} \mathrm{~N} \mathrm{ha}^{-1}$, IPSA $5(78.33 \mathrm{~cm})$ at $80 \mathrm{~kg} \mathrm{~N} \mathrm{ha}^{-1}$, ACC $12980053(75.00 \mathrm{~cm})$ at $40 \mathrm{~kg} \mathrm{~N} \mathrm{ha}^{-1}$, BU mug $4(60.06 \mathrm{~cm})$ at $40 \mathrm{~kg} \mathrm{~N} \mathrm{ha}^{-1}$, BARI Mung $6(57.00 \mathrm{~cm})$ at $60 \mathrm{~kg} \mathrm{~N} \mathrm{ha}^{-1}$ and Binamoog $5(68.33 \mathrm{~cm})$ at $60 \mathrm{~kg} \mathrm{~N} \mathrm{ha}^{-1}$. The lowest plant height was obtained at $\mathrm{o} \mathrm{kg} \mathrm{ha-1}$ irrespective of genotypes. The results revealed that genotypes itself are responsible for variation in plant height while applied nitrogen enhanced the growth of mungbean. Increase in plant height of mungbean at higher nitrogen levels may be ascribed to increase of $\mathrm{N}$ in chlorophyll which increased photosynthesis and enhanced meristematic activity of plant (Sawwar et al., 1989). Besides, nitrogen is essential component of amino acids which are vital building blocks for development of tissues and consequently increased plant height. This result is an agreement with the findings of Rahman et al. (1992) of French bean at higher level of nitrogen $\left(120 \mathrm{~kg} \mathrm{ha}^{-1}\right)$.

Table 2. Plant height $(\mathrm{cm})$ of mungbean genotypes as affected by nitrogen level.

\begin{tabular}{l|c|c|c|c|cc}
\hline \multirow{2}{*}{ Genotypes } & \multicolumn{6}{c}{ Nitrogen levels $\left(\mathrm{kg} \mathrm{ha}^{-1}\right)$} \\
\cline { 2 - 7 } & 0 & 20 & 40 & 60 & 80 & 100 \\
\hline IPSA -12 & $50.00 \mathrm{cC}$ & $54.66 \mathrm{bB}$ & $56.66 \mathrm{bC}$ & $63.66 \mathrm{aB}$ & $57.00 \mathrm{bC}$ & $48.66 \mathrm{cC}$ \\
GK -27 & $40.00 \mathrm{bC}$ & $42.66 \mathrm{aC}$ & $43.00 \mathrm{aD}$ & $42.66 \mathrm{aC}$ & $42.66 \mathrm{aC}$ & $40.00 \mathrm{bC}$ \\
IPSA-3 & $63.00 \mathrm{abA}$ & $64.66 \mathrm{aAB}$ & $62.40 \mathrm{bC}$ & $63.00 \mathrm{abB}$ & $65.33 \mathrm{aB}$ & $63.00 \mathrm{abB}$ \\
IPSA -5 & $58.30 \mathrm{cB}$ & $63.44 \mathrm{cAB}$ & $69.00 \mathrm{bB}$ & $63.00 \mathrm{bbB}$ & $78.33 \mathrm{aA}$ & $69.66 \mathrm{bA}$ \\
ACC12890055 & $61.56 \mathrm{bcA}$ & $63.00 \mathrm{bAB}$ & $65.66 \mathrm{bB}$ & $62.00 \mathrm{bB}$ & $78.66 \mathrm{aA}$ & $58.61 \mathrm{cBC}$ \\
GK -63 & $44.96 \mathrm{bC}$ & $47.37 \mathrm{aC}$ & $47.00 \mathrm{aD}$ & $43.00 \mathrm{bcC}$ & $41.66 \mathrm{bcC}$ & $41.00 \mathrm{cC}$ \\
ACC12890053 & $56.64 \mathrm{cB}$ & $68.66 \mathrm{bA}$ & $75.00 \mathrm{aA}$ & $71.33 \mathrm{abA}$ & $70.65 \mathrm{abA}$ & $70.00 \mathrm{abA}$ \\
BUmug -4 & $43.66 \mathrm{bcC}$ & $46.06 \mathrm{cC}$ & $60.60 \mathrm{aC}$ & $59.00 \mathrm{aC}$ & $42.66 \mathrm{cC}$ & $43.00 \mathrm{bcC}$ \\
BARI Mung -6 & $41.66 \mathrm{cC}$ & $44.12 \mathrm{cC}$ & $54.00 \mathrm{abC}$ & $57.00 \mathrm{aC}$ & $53.66 \mathrm{aC}$ & $51.33 \mathrm{abC}$ \\
Binamoog -5 & $54.33 \mathrm{cBC}$ & $65.00 \mathrm{abA}$ & $65.0 \mathrm{abB}$ & $68.33 \mathrm{aAB}$ & $60.33 \mathrm{bcB}$ & $58.33 \mathrm{bcBC}$ \\
\hline
\end{tabular}

Means followed by same small letter (row) and capital letter (column) did not differ significantly at $5 \%$ level of probability. 


\section{Yield components and yield}

\section{Pods plant ${ }^{-1}$}

Number of pods plant ${ }^{-1}$ of mungbean genotypes significantly influenced by the $\mathrm{N}$ levels. Increasing nitrogen level led to increase pod plant ${ }^{-1}$ up to $60 \mathrm{~kg} \mathrm{~N}^{\mathrm{N}} \mathrm{ha}^{-1}$ irrespective of genotypes and thereafter decreased due to increase in $\mathrm{N}$ rates (Table 3). These results are agreed with the findings of Peter and Patel (1991) they reported that number of pod plant ${ }^{-1}$ of mungbean increased with application of nitrogen fertilizer and excess application reduced pod number of mungbean. There were genotypic variations in pod development where the genotype IPSA 12 produced the highest pods plant ${ }^{-1}$ (30.16) with $60 \mathrm{~kg} \mathrm{~N}^{-1}$ and it was statistically similar to IPSA 5 at same $\mathrm{N}$ level (Table 3 ). The lowest number of pods plant ${ }^{-1}$ (16.16) was recorded in genotype GK- 63 which was identical with pods plant ${ }^{-1}$ (16.83) with Binamoog-5 with $100 \mathrm{~kg} \mathrm{~N} \mathrm{ha}^{-1}$. Control plant (no fertilizer with $\mathrm{N}$ ) produced lower number of pods in all the mungbean genotypes. Plant absorbed nutrient from the soil which is required in the formation of seed is not sufficient in control condition. Increased nitrogen level in the no fertile soil were increased nutrient availability and increased number of pod plant ${ }^{-1}$ up to 60 $\mathrm{kg} \mathrm{N} \mathrm{ha}{ }^{-1}$.Further increased nitrogen levels nutrient toxicity occur and decreased pod plant ${ }^{-1}$. These results are supported by Ashraf (2001) that number of pods plant $^{-1}$ was significantly affected by application of $\mathrm{N}$ fertilizer. These means that mungbean genotypes require additional $\mathrm{N}$ for better pod development although it is capable to fix atmospheric $\mathrm{N}$ through rhizobium species living in root nodules (Anjum et al., 2006).

Table 3. Number of pods per plant of mungbean genotype as affected by nitrogen level.

\begin{tabular}{l|ccc|c|c|c}
\hline \multirow{2}{*}{ Genotype } & \multicolumn{6}{c}{ Nitrogen levels $\left(\mathrm{kg} \mathrm{ha}^{-1}\right)$} \\
\cline { 2 - 7 } & $\mathrm{N}_{0}$ & $\mathrm{~N}_{20}$ & $\mathrm{~N}_{40}$ & $\mathrm{~N}_{60}$ & $\mathrm{~N}_{80}$ & $\mathrm{~N}_{100}$ \\
\hline IPSA 12 & $22.00 \mathrm{cA}$ & $24.83 \mathrm{bcA}$ & $27.50 \mathrm{bA}$ & $30.16 \mathrm{aA}$ & $26.16 \mathrm{bA}$ & $22.66 \mathrm{cA}$ \\
GK 27 & $20.00 \mathrm{bA}$ & $22.50 \mathrm{abAB}$ & $23.60 \mathrm{aB}$ & $23.50 \mathrm{aC}$ & $22.33 \mathrm{abB}$ & $19.66 \mathrm{bB}$ \\
IPSA 3 & $19.66 \mathrm{cAB}$ & $22.16 \mathrm{bAB}$ & $23.16 \mathrm{bB}$ & $25.16 \mathrm{aB}$ & $22.50 \mathrm{bB}$ & $20.33 \mathrm{bcB}$ \\
IPSA 5 & $21.83 \mathrm{bcA}$ & $25.33 \mathrm{aA}$ & $26.33 \mathrm{aA}$ & $27.50 \mathrm{aB}$ & $26.00 \mathrm{aA}$ & $23.16 \mathrm{bA}$ \\
ACC12890055 & $20.16 \mathrm{cA}$ & $23.00 \mathrm{abAB}$ & $23.16 \mathrm{abB}$ & $25.00 \mathrm{aB}$ & $21.66 \mathrm{bB}$ & $20.83 \mathrm{bcB}$ \\
GK 63 & $16.83 \mathrm{cC}$ & $21.33 \mathrm{bB}$ & $21.63 \mathrm{bC}$ & $23.33 \mathrm{aC}$ & $22.33 \mathrm{abB}$ & $17.16 \mathrm{cC}$ \\
ACC12890053 & $20.33 \mathrm{cA}$ & $22.00 \mathrm{bcAB}$ & $22.66 \mathrm{bC}$ & $25.83 \mathrm{aB}$ & $22.00 \mathrm{bB}$ & $22.16 \mathrm{bA}$ \\
BU mug 4 & $19.00 \mathrm{cAB}$ & $22.00 \mathrm{bAB}$ & $24.16 \mathrm{aAB}$ & $25.16 \mathrm{aC}$ & $21.83 \mathrm{bBC}$ & $21.00 \mathrm{bcAB}$ \\
BARI Mung 6 & $18.93 \mathrm{cB}$ & $20.50 \mathrm{bB}$ & $22.50 \mathrm{abC}$ & $23.33 \mathrm{aC}$ & $22.33 \mathrm{aB}$ & $20.83 \mathrm{bBC}$ \\
Binamoog 5 & $16.83 \mathrm{dC}$ & $19.83 \mathrm{cC}$ & $23.33 \mathrm{aB}$ & $24.83 \mathrm{aC}$ & $21.50 \mathrm{bB}$ & $17.66 \mathrm{dC}$ \\
\hline
\end{tabular}

Means followed by same small letter (row) and capital letter (column) did not differ significantly at $5 \%$ level of probability. 


\section{Seeds pod ${ }^{-1}$}

Interaction effect of genotype and nitrogen was not significant but genotype had significant effects on seeds pod ${ }^{-1}$ of mungbean (Table 4.). The highest seed pod ${ }^{-1}$ (12.40) was obtained in IPSA 12 and the lowest seed $\operatorname{pod}^{-1}(10.20)$ was recorded in BUmug 4 at o $\mathrm{kg} \mathrm{N} \mathrm{ha}^{-1}$. Seed pod $^{-1}$ was highest in IPSA 12 in control condition because lower number of pod plant ${ }^{-1}$ were obtained in this condition and more nutrient were available in formation in seed but not significantly different with other nitrogen level. These findings are agreed with Asaduzzaman et al. (2008) where they reported that nitrogen level and irrigation had no significant effect on seeds pod ${ }^{-1}$. The number of seeds pod $^{-1}$ is mostly genetically controlled but its number may be regulated by canopy photosynthesis during pod developing stage. Seed number also may be limited by the activity of the source (Akther, 2005). During seed filling, the ability of the individual seed to utilize assimilate determines number of seeds pod $^{-1}$ and limitation of assimilate reduce the seeds pod $^{-1}$ (Jenner et al. 1992). This results however contrasting with the findings of Rashid et al. (1999) who reported that application of $\mathrm{N}$ fertilizer increases seeds pod $^{-1}$ significantly.

Table 4. Number of seeds per pod of mungbean genotype as affected by nitrogen levels.

\begin{tabular}{l|c|c|c|c|c|c}
\hline \multirow{2}{*}{ Genotypes } & \multicolumn{7}{|c}{ Nitrogen levels $\left(\mathrm{kg} \mathrm{ha}^{-1}\right)$} \\
\cline { 2 - 7 } & 0 & 20 & 40 & 60 & 80 & 100 \\
\hline IPSA 12 & $12.40 \mathrm{~A}$ & $12.33 \mathrm{~A}$ & $12.13 \mathrm{~A}$ & $12.03 \mathrm{~A}$ & $11.66 \mathrm{~A}$ & $11.83 \mathrm{~A}$ \\
GK-27 & $10.93 \mathrm{~A}$ & $11.11 \mathrm{~A}$ & $10.85 \mathrm{~A}$ & $10.76 \mathrm{~B}$ & $10.76 \mathrm{~B}$ & $10.66 \mathrm{~B}$ \\
IPSA 3 & $11.65 \mathrm{~A}$ & $11.20 \mathrm{~A}$ & $11.91 \mathrm{~A}$ & $11.08 \mathrm{~A}$ & $11.38 \mathrm{~A}$ & $11.05 \mathrm{~A}$ \\
IPSA 5 & $11.46 \mathrm{~A}$ & $12.15 \mathrm{~A}$ & $11.98 \mathrm{~A}$ & $11.96 \mathrm{~A}$ & $11.60 \mathrm{~A}$ & $11.86 \mathrm{~A}$ \\
ACC12890055 & $10.60 \mathrm{~B}$ & $11.20 \mathrm{~A}$ & $11.16 \mathrm{~A}$ & $11.20 \mathrm{~A}$ & $11.00 \mathrm{~A}$ & $11.05 \mathrm{~A}$ \\
GK-63 & $10.83 \mathrm{~B}$ & $11.23 \mathrm{~A}$ & $11.20 \mathrm{~A}$ & $11.36 \mathrm{~A}$ & $10.83 \mathrm{~A}$ & $10.23 \mathrm{~A}$ \\
ACC12890053 & $10.40 \mathrm{~B}$ & $11.65 \mathrm{~A}$ & $11.25 \mathrm{~A}$ & $10.66 \mathrm{~B}$ & $11.23 \mathrm{~A}$ & $10.40 \mathrm{~B}$ \\
BU mug 4 & $10.20 \mathrm{~B}$ & $10.84 \mathrm{~A}$ & $10.65 \mathrm{~B}$ & $11.15 \mathrm{~A}$ & $11.06 \mathrm{~A}$ & $11.20 \mathrm{~A}$ \\
BARI Mung 6 & $10.30 \mathrm{~B}$ & $10.76 \mathrm{~A}$ & $10.75 \mathrm{~B}$ & $11.01 \mathrm{~A}$ & $11.40 \mathrm{~A}$ & $11.11 \mathrm{~A}$ \\
Binamoog 5 & $11.40 \mathrm{~A}$ & $11.28 \mathrm{~A}$ & $10.73 \mathrm{~B}$ & $11.13 \mathrm{~A}$ & $11.10 \mathrm{~A}$ & $11.54 \mathrm{~A}$ \\
\hline
\end{tabular}

Means followed by same capital letter (column) did not differ significantly at $5 \%$ level of probability.

\section{0 - seed weight}

Thousand seeds weight was not significantly affected by $\mathrm{N}$ fertilizer application as it is largely governed by genetic factors. Thus, 1000- seeds weight varied in among the mungbean genotypes where maximum 1000 -seed weight $(50.2 \mathrm{~g})$ was recorded in GK -27 which was similar $(50.1 \mathrm{~g})$ to GK 63 and the lowest seed 
size (34.2 g) was recorded in ACC12890053 (Table 5). In present study although, soil $\mathrm{N}$ fertilizer failed to enhanced 1000 -seed weight but it increased in faba bean (Elsheikh and Elzidany, 1997) and groundnut (Chetti et al., 1995) due to soil $\mathrm{N}$ fertilizer application.

Table 5. Effect of nitrogen fertilizer on 1000 -seed weight (g) of mungbean genotypes.

\begin{tabular}{l|c|c|c|c|c|c}
\hline \multirow{2}{*}{ Genotypes } & \multicolumn{7}{|c}{ Nitrogen levels $\left(\mathrm{kg} \mathrm{ha}^{-1}\right)$} \\
\cline { 2 - 7 } & 0 & 20 & 40 & 60 & 80 & 100 \\
\hline IPSA 12 & 41.5 & 38.8 & 38.7 & 39.2 & 40.7 & 40.3 \\
GK-27 & 50.2 & 49.4 & 49.9 & 49.9 & 49.7 & 49.8 \\
IPSA 3 & 47.1 & 47.7 & 46.5 & 47.8 & 45.5 & 46.1 \\
IPSA 5 & 38.5 & 38.1 & 39.5 & 41.5 & 41.0 & 36.8 \\
ACC12890055 & 43.7 & 46.2 & 45.7 & 43.9 & 45.9 & 42.9 \\
GK-63 & 49.8 & 50.1 & 49.9 & 49.4 & 49.6 & 49.7 \\
ACC12890053 & 34.7 & 34.2 & 35.8 & 34.9 & 37.7 & 34.5 \\
BU mug- 4 & 46.1 & 43.4 & 41.6 & 40.3 & 43.5 & 40.8 \\
BARI Mung -6 & 49.3 & 48.9 & 48.9 & 50.0 & 49.0 & 48.6 \\
Binamoog -5 & 39.0 & 40.3 & 37.2 & 37.0 & 40.7 & 41.1 \\
\hline
\end{tabular}

\section{Seed yield plant $^{-1}$}

Seed yield plant $^{-1}$ was significantly affected by the interaction of mungbean genotypes and $\mathrm{N}$ fertilizer applications. Seed yield of mungbean varied from 7.33 $\mathrm{g}$ to $14.22 \mathrm{~g} \mathrm{plant}^{-1}$ and it was the highest in IPSA $12\left(14.22 \mathrm{~g} \mathrm{plant}^{-1}\right)$ grown with $60 \mathrm{~kg} \mathrm{~N} \mathrm{ha}^{-1}$ and the lowest in ACC12890053(7.33 $\mathrm{g}$ plant $\left.^{-1}\right)$ under control condition (Table 6). The genotype IPSA 12 however respond well $\left(11.32 \mathrm{~g} \mathrm{plant}^{-}\right.$ $\left.{ }^{1}\right)$ under control condition. There was general trend of increase seed yield with the increase of $\mathrm{N}$ fertilizer up to $60 \mathrm{~kg} \mathrm{~N} \mathrm{ha}^{-1}$ and thereafter decreased. Increase nitrogen fertilizer in low fertile soil gradually increased seed yield upto $60 \mathrm{~kg} \mathrm{~N}$ ha $^{-1}$ due to increase pod plant ${ }^{-1}$. These findings agreed with Biswas and Hamid (1989) and Mitra and Ghildiyal (1988) that seed yield of mungbean is limited by nitrogen supply. Application of $\mathrm{N}$ fertilizer upto $60 \mathrm{~kg} \mathrm{~N} \mathrm{ha}^{-1}$ enhanced leaf area, dry matter production and consequently improved number of pods plant ${ }^{-1}$ and seeds pod $^{-1}$ of mungbean genotypes and hence increased the yield. Plants grown without added nitrogen or lower levels of fertilizer produced the lowest seed yield plant $^{-1}$ irrespective of genotypes. the negative response of higher $\mathrm{N}$ doses (beyond $60 \mathrm{~kg} \mathrm{~N} \mathrm{ha}^{-1}$ ) might be the toxic effect or produced some barriers on nutrition of mungbean plants. Yield of mungbean decrease in beyond $60 \mathrm{~kg} \mathrm{~N}$ $\mathrm{ha}^{-1}$ may be explained by quadratic equation $\mathrm{y}=9.37+0.101 \mathrm{x}-0.001 \mathrm{x}^{2}$ as illustrated in Fig. 1. This equation states that seed yield of mungbean is 
maximum (11.92 $\left.\mathrm{g} \mathrm{plant}^{-1}\right)$ at $54 \mathrm{~kg} \mathrm{~N} \mathrm{ha}^{-1}$ and thereafter, yield decrease at the rate of $0.001 \mathrm{x}^{2}$ for each unit of applied $\mathrm{N}$ fertilizer. The value of R2 (0.97) indicates that the nitrogen rates can account for $97 \%$ of the total variable in each yield.

Table 6. Seed yield $\left(\mathrm{g}\right.$ plant $^{-1}$ ) of mungbean genotype as affected by nitrogen fertilizer.

\begin{tabular}{l|ccccccc}
\hline \multirow{2}{*}{ Genotypes } & \multicolumn{7}{|c}{ Nitrogen levels $\left(\mathrm{kg} \mathrm{ha}^{-1}\right)$} \\
\cline { 2 - 7 } & 0 & 20 & 40 & 60 & 80 & 100 \\
\hline IPSA 12 & $11.32 \mathrm{Ac}$ & $11.87 \mathrm{Ac}$ & $12.87 \mathrm{Ab}$ & $14.22 \mathrm{Aa}$ & $12.41 \mathrm{Ab}$ & $10.80 \mathrm{Ac}$ \\
GK-27 & $10.97 \mathrm{Ab}$ & $12.34 \mathrm{Aa}$ & $12.80 \mathrm{Aa}$ & $12.61 \mathrm{Ba}$ & $11.94 \mathrm{Ab}$ & $10.43 \mathrm{Ab}$ \\
IPSA 3 & $10.78 \mathrm{Abc}$ & $11.83 \mathrm{Ab}$ & $12.82 \mathrm{Aa}$ & $13.32 \mathrm{ABa}$ & $11.65 \mathrm{Ab}$ & $10.35 \mathrm{Ac}$ \\
IPSA 5 & $9.60 \mathrm{Bc}$ & $11.72 \mathrm{Ab}$ & $12.45 \mathrm{Aa}$ & $13.64 \mathrm{Aa}$ & $12.36 \mathrm{Aa}$ & $10.10 \mathrm{Abc}$ \\
ACC12890055 & $9.33 \mathrm{Bc}$ & $11.90 \mathrm{Aab}$ & $11.81 \mathrm{Bab}$ & $12.29 \mathrm{Ba}$ & $10.93 \mathrm{Bb}$ & $9.87 \mathrm{ABb}$ \\
GK-63 & $10.06 \mathrm{Bb}$ & $12.00 \mathrm{Aa}$ & $12.20 \mathrm{Ba}$ & $13.09 \mathrm{Ba}$ & $11.99 \mathrm{Aa}$ & $9.23 \mathrm{ABb}$ \\
ACC12890053 & $7.33 \mathrm{Dcd}$ & $8.49 \mathrm{Db}$ & $9.12 \mathrm{Cab}$ & $9.60 \mathrm{Ca}$ & $9.31 \mathrm{BCab}$ & $7.95 \mathrm{Cc}$ \\
BU mug 4 & $8.93 \mathrm{Bbc}$ & $10.35 \mathrm{Bab}$ & $10.85 \mathrm{Ba}$ & $11.14 \mathrm{Ba}$ & $10.40 \mathrm{Bab}$ & $9.59 \mathrm{ABbc}$ \\
BARI Mung -6 & $8.55 \mathrm{Bbc}$ & $10.78 \mathrm{Bb}$ & $11.82 \mathrm{Bab}$ & $12.84 \mathrm{Aa}$ & $12.40 \mathrm{Aa}$ & $11.24 \mathrm{Aab}$ \\
Binamoog 5 & $7.48 \mathrm{Dc}$ & $8.61 \mathrm{Cb}$ & $9.31 \mathrm{BCab}$ & $10.23 \mathrm{Ca}$ & $9.71 \mathrm{Cab}$ & $8.37 \mathrm{Cbc}$ \\
\hline
\end{tabular}

Means followed by same small letter (row) and capital letter (column) did not differ significantly at $5 \%$ level of probability.

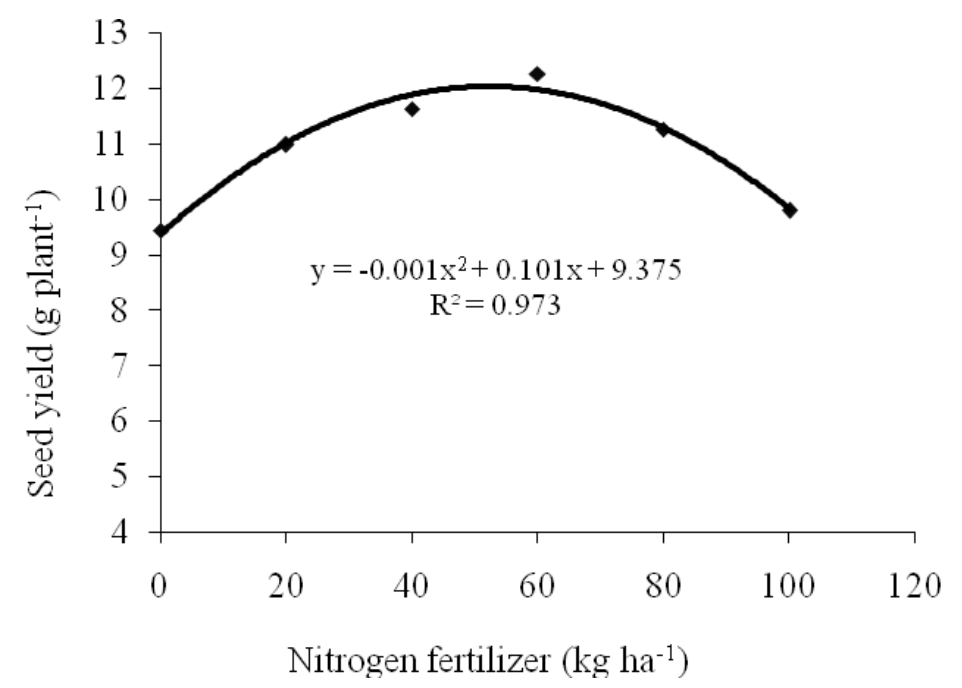

Fig. 1. Relationship between nitrogen fertilizer and seed yield of mungbean genotypes. 


\section{Nitrogen acquisition}

As nitrogen deficiency in soil of Bangladesh is common (FRG, 2005), the ability of the plants to acquire nitrogen and their efficient use is important for crop adaptation to soils with low fertility. Genotypic differences in nitrogen acquisition revealed that the genotype IPSA 12 acquired maximum amount of nitrogen $\left(0.767 \mathrm{~g} \mathrm{plant}^{-1}\right)$ under $60 \mathrm{~kg} \mathrm{~N} \mathrm{ha}^{-1}$ and it was the lowest in Binamoog $5\left(0.381 \mathrm{~g} \mathrm{plant}^{-1}\right)$ at control condition (Table 7). It was observed that most of the mungbean genotype acquired maximum nitrogen at 40 or $60 \mathrm{~kg} \mathrm{~N} \mathrm{ha}^{-1}$ except ACC12890053. This genotype needs even $80 \mathrm{~kg} \mathrm{~N} \mathrm{ha}^{-1}$ to acquire maximum nitrogen which supposed to be very expensive. Nitrogen regulates soil $\mathrm{pH}$ through $\mathrm{NH}+$ and increases $\mathrm{P}$ availability (Havlin et al., 2006), and phosphorus enhances nodulation and subsequently accumulates more $\mathrm{N}$ in mungbean plants (Marschner et al., 1997).

Table 7. Plant nitrogen acquisition (g plant $\left.{ }^{-1}\right)$ of mungbean genotypes as affected by different nitrogen levels.

\begin{tabular}{l|c|c|c|c|c|c}
\hline \multirow{2}{*}{ Genotypes } & \multicolumn{7}{|c}{ Nitrogen levels $\left(\mathrm{kg} \mathrm{ha}^{-1}\right)$} \\
\cline { 2 - 7 } & $\mathrm{N}_{0}$ & $\mathrm{~N}_{20}$ & $\mathrm{~N}_{40}$ & $\mathrm{~N}_{60}$ & $\mathrm{~N}_{80}$ & $\mathrm{~N}_{100}$ \\
\hline IPSA 12 & 0.536 & 0.639 & 0.710 & 0.767 & 0.662 & 0.591 \\
GK -27 & 0.437 & 0.495 & 0.533 & 0.531 & 0.531 & 0.483 \\
IPSA 3 & 0.480 & 0.506 & 0.530 & 0.604 & 0.555 & 0.506 \\
IPSA 5 & 0.430 & 0.537 & 0.650 & 0.676 & 0.643 & 0.541 \\
ACC12890055 & 0.472 & 0.614 & 0.674 & 0.601 & 0.579 & 0.510 \\
GK -63 & 0.402 & 0.481 & 0.508 & 0.525 & 0.480 & 0.446 \\
ACC12890053 & 0.412 & 0.527 & 0.584 & 0.630 & 0.620 & 0.526 \\
BUmug 4 & 0.420 & 0.516 & 0.565 & 0.531 & 0.517 & 0.484 \\
BARI Mung -6 & 0.433 & 0.492 & 0.560 & 0.595 & 0.554 & 0.501 \\
Bina moog 5 & 0.381 & 0.443 & 0.534 & 0.556 & 0.519 & 0.46 \\
\hline
\end{tabular}

\section{Conclusion}

The results revealed that nitrogen is necessary to ensure better growth and productivity of mungbean with low fertile soil. Increased $\mathrm{N}$ level mungbean production increased up to $60 \mathrm{~kg} \mathrm{~N} \mathrm{ha}^{-1}$ in low fertile soil irrespective of genotypes. The genotype IPSA 12 performed the best in low fertile soil. The optimum dose of nitrogen for mungbean cultivation in the low fertile soil is $54 \mathrm{~kg} \mathrm{ha}^{-1}$.

\section{References}

Akbari, N., M. Barani and H. Ahmadi. 2008. Change of grain protein content and correlations with other characteristics under planting pattern and starter $\mathrm{N}$ fertilizer of mungbean (Vigna radiata L. Wilczek). Am. Eurasian J.Agric. Environ. Sci. 4: 306-310. 
Akther, M. S. 2005. Physiological differences in yielding ability of traditional and modern mungbean genotypes (Vigna radiata (L) Wilczek). A $\mathrm{Ph} \mathrm{D}$ thesis submitted Department of Agronomy, BSMRAU, Gazipur. Pp. 56

Anjum, M. S., Z. I. Ahmed and C. A. Rauf. 2006. Effect of Rhizobium inoculation and nitrogen fertilizer on yield and yield components of mungbean. Int. J. Agric. and Biol. 8: 238-240.

Asaduzzaman, M., M. F. Karim., M. J. Ullah and M. Hasunuzzaman. 2008. Response of mungbean (Vigna radiata) to nitrogen and irrigation management. Am. Eurosia J. Sci. Res. 3: 40-43.

Ashraf. M. 2001. Influence of seed inoculation and NPK application on growth, yield and quality of mungbean (Vigna radiata L.Wilczek) cv. NM-98. M Sc Thesis, Department of Agronomy . University of Agric. Faisalabad, Pakistan.

FRG, 2005. Fertilizer Recommendation Guide, Bangladesh Agricultural Research Council, Farmgate, Dhaka.

Biswas, J. C and A, Hamid. 1989. Influence of carbofuran on leaf senescenes and nitrogen uptake of mungbean (Vigna radiata) Bangladesh J. Agric. 14: 261-267.

Chetti, M. B., E. Antony, U. V. Mummigatti and M. B. Dodammi. 1995. Role of nitrogen and rhizobium on nitrogen fixation on nitrogen utilization efficiency and productivity potential of groundnut genotypes. Farming systems, 11:25-33.

Elsheikh, E. A. E and A. A. Elzidany.1997. Effects of rhizobium inoculation, organic and chemical fertilizers on yield and physical properties of faba bean seed. Pl.Food Hum. Nutr. 51: 137- 144.

Haque, M. M., M. A. Afzal, A Hamid, M Abu bakr, Q. A. Khaliq and M. A. Hossain. 2001.

Improvement variety of mungbean: BUmug 2, Publication no. 21. Lentil Blackgram and Mungbean development pilot project, PRS, BARI. Gazipur. Pp. 6

Hardarson, G and S. K. A. Danso. 1993. Methods for measuring biological nitrogen fixation in grain legumes, Plant and Soil. 152: 19-23.

Havlin, J. L., J. D.Beaton., S. L. Tisdale and W. I. Nelson. 2006. Soil fertility and fertilizer. An introduction to nutrient management. $7^{\text {th }}$ edition. p. 515. Asoke K. Ghose. Printed Hall, New Delhi, publishers, India.

Jenner, C. F., T. D. Ugalde and D. Aspinall. 1992. The physiology of starch and protein deposition in the endosperm of wheat. Aust. J. Plant Physiol. 18: 211-226.

Malik, M. A., S. Hussain, E. A. Warruich, A. Habib and S. Ullah. 2002. Effects of seed inoculation and phosphorus application on growth, seed yield and quality of mungbean (Vigna radiata L.) CV NM-98. Int. J. Agri. Biol. 4(4): 515-516.

Marschner, H. E., E. A. Kirby and C. Engels. 1997. Importance of cycling and ecycling of mineral nutrients winter plants for growth and development. Bot. Acta. 265-273.

Mitra, S and M. C. Ghildiyal. 1988. Photosynthesis and assimilates partitioning in mungbean in response to source sink alterations. J. Agron and Crop Sci. 160: 303308 . 
Pater, F. M and L. R. Patel. 1991.Response of greengram varieties to phosphorus and rhizobium inoculation. Indian A. Agron. 36: 355-356.

Rahman, M. M., A. A. Miah, A. Hamid and A.F. M. Moniruzzaman. 1992. Growth analysis of chickpea genotype in relation to grain filling period and yield potential. Bangladesh J. Bot. 21: 225-231.

Rashid, A., M. Musa, N. K. Aadal, M. Yaqub and G. A. Choudhury. 1999. Response to groundnut to Bradyrhizobium and Diazotroph bacterial inoculums under different levels of nitrogen. Pakistan J. Soil. 16: 89-98

Sawwar, Z. M., M. S. Maddab Eldis and B. Gregg. 1989. Influence of nitrogen, phosphorus and growth regulators on seed yield and viability and seedling vigour of Egyptian cotton. Seed Sci. and Technol. 17: 507-509. 